Review

\title{
Technological Aspects of Chemoenzymatic Epoxidation of Fatty Acids, Fatty Acid Esters and Vegetable Oils: A Review
}

\author{
Eugeniusz Milchert*, Kornelia Malarczyk and Marlena Kłos \\ Received: 9 October 2015 ; Accepted: 17 November 2015 ; Published: 2 December 2015 \\ Academic Editor: Lajos Novak \\ Institute of Organic Chemical Technology, Faculty of Chemical Engineering, West Pomeranian University of \\ Technology Szczecin, 10 Pulaski St., 70-322 Szczecin, Poland; Kornelia.Malarczyk@zut.edu.pl (K.M.); \\ Marlena.Klos@zut.edu.pl (M.K.) \\ * Correspondence: milch@zut.edu.pl; Tel.: +48-91-449-48-55
}

\begin{abstract}
The general subject of the review is analysis of the effect of technological parameters on the chemoenzymatic epoxidation processes of vegetable oils, fatty acids and alkyl esters of fatty acids. The technological parameters considered include temperature, concentration, amount of hydrogen peroxide relative to the number of unsaturated bonds, the amounts of enzyme catalysts, presence of solvent and amount of free fatty acids. Also chemical reactions accompanying the technological processes are discussed together with different technological options and significance of the products obtained.
\end{abstract}

Keywords: fatty acids; alkyl fatty acid esters; free fatty acids; epoxidation

\section{Introduction}

Epoxidized vegetable oils and the products of their transformations-fatty acids and alkyl esters of fatty acids-are in widespread use. Epoxidized vegetable oils are used as solvents [1], lubricants [2-5], prepolymers in surface coating formulations [6-9], stabilizers (PVC) and plastics plasticizers [10-15], asphalt additives and transformer fluids [16]. They are used for production of polyetherpolyols and polyesterpolyols as intermediates in polyurethane production $[14,15,17]$, block copolymers in polyester resin production [18], and nanocomposites. Using epoxidized oils it is possible to obtain polymers and composites with better mechanical [19-21], electric [22], thermal [23] properties than those of the polymers obtained from petrochemical products $[20,22]$ and greater resistance to oxidation [22,23] than the latter ones. Epoxidized oils are auxiliary agents used to improve the efficiency of linoleum flooring production and modification of other thermoset polymers [24-26]. They are important intermediates in organic synthesis as they participate in many reactions thanks to the high reactivity of oxirane rings [27].

\section{The Methods for Epoxidation of Vegetable Oils}

There are a few industrially important vegetable oil epoxidation methods:

- Reaction with pre-produced peroxyacids or generated in situ in acidic homogeneous medium [23,28-32],

- Epoxidation with peroxyacids in the presence of cationic ion-exchange resins (Amberlite ${ }^{\circledR}$ IR-122, Amberlite IR 120H, KU-2 × 8) [33-45],

- Epoxidation over phosphotungstate heteropolyacid catalysts and in the presence of phase-transfer catalysts $\left(\mathrm{H}^{+} / \mathrm{WO}_{4}{ }^{-2} / \mathrm{PO}_{4}{ }^{-3} / \mathrm{Q}^{+} \mathrm{X}^{-}\right)$, QX-onium salt [42,43], 
- Epoxidation over titanium-silicalite catalysts (Ti(IV)- $\mathrm{SiO}_{2}$, Ti-MCM-41, and amorphous $\left.\mathrm{Ti} / \mathrm{SiO}_{2}\right)[39,44,46,47]$,

- Epoxidation in the presence of transition metal complexes as catalysts $\left(\mathrm{CH}_{3} \mathrm{ReO}_{3}\right.$ or $\mathrm{CH}_{3} \mathrm{ReO}_{3} / \mathrm{Nb}$ ) [48,49],

- Epoxidation in the presence of aluminium trioxide, obtained by a sol-gel method [50],

- Chemoenzymatic epoxidation [28,51-55].

The first of the abovementioned methods is used for the industrial scale production of soybean and rapeseed oils. In 2013 the production reached more than 200,000 metric tons per year of epoxidized soybean oil. The yields of the processes are different. Not all oils can be epoxidized using peracids (tung oil, for example) which is related to the content and type of unsaturated acids in triglycerides. Other vegetable oils that can be epoxidized include: linseed, corn, safflower, melon seed, cotton seed [56], rubber seed oil [57,58]. Epoxidations of inedible vegetable oils like canola [36], mahua [28], jatropha [38], and karanja [34] have been reported.

\section{Reactions of Chemoenzymatic Epoxidation}

Chemoenzymatic epoxidation is performed in the presence of Candida antarctica lipase B (CALB), CALB immobilized onto an acrylic resin (Novozym ${ }^{\circledR} 435$ ) or Candida antarctica lipase B immobilized onto silica (CALB-silica) and another lipases as catalysts. Lipases can also catalyse the hydrolysis of triglycerides, alcoholysis, acidolysis, esterification, interesterification and aminolysis. In the presence of hydrogen peroxide and lipase unsaturated and/or saturated fatty acids are transformed into peroxyacids. Novozym ${ }^{\circledR} 435$ shows a high enzymatic activity among the hitherto examined enzymes [57]. The actual epoxidizing agent is the peroxyacid, while carboxylic acid acts as oxygen carriers. Unsaturated peroxyacids can also undergo self-epoxidation, according to the reaction $[51-54,59]$ shown in Scheme 1:

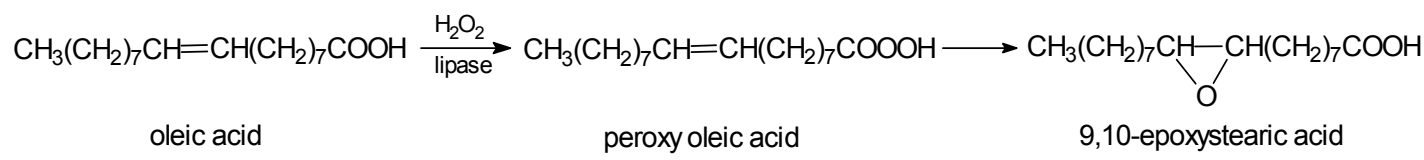

Scheme 1. Chemo-enzymatic self-epoxidation of unsaturated fatty acids: conversion of oleic acid to epoxystearic acid.

In this case unsaturated fatty acids are converted into unsaturated peroxyacids thanks to the perhydrolysis activity of lipase, and then unsaturated peroxy or carboxylic acids are epoxidized via the classical uncatalyzed reaction referred to as self-epoxidation. In fact it proceeds mostly via an intermolecular process [53]. Epoxidized fatty acid can also form epoxidized peroxy fatty acids, which are also epoxidizing agents (Scheme 2):

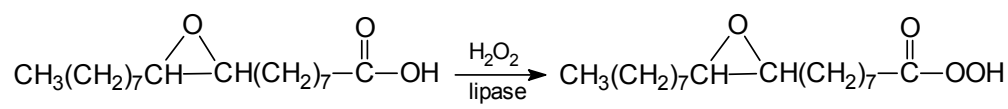

Scheme 2. Formation of epoxidized peroxy fatty acids.

The alkyl esters of carboxylic acids, in the presence of enzyme lipase and hydrogen peroxide, undergo perhydrolysis with formation of the corresponding peroxy acids (Scheme 3):

$$
\stackrel{\mathrm{O}}{\mathrm{C}}-\mathrm{O}-\mathrm{OR}_{1} \underset{30 \% \mathrm{H}_{2} \mathrm{O}_{2}}{\stackrel{\text { lipase }}{\longrightarrow}} \mathrm{R}-\stackrel{\mathrm{O}}{\mathrm{C}}-\mathrm{OOH}+\mathrm{R}_{1} \mathrm{OH}
$$

Scheme 3. The reaction of carboxylic acids esters with hydrogen peroxide. 
Glycerides undergo perhydrolysis in a similar way (Scheme 4):

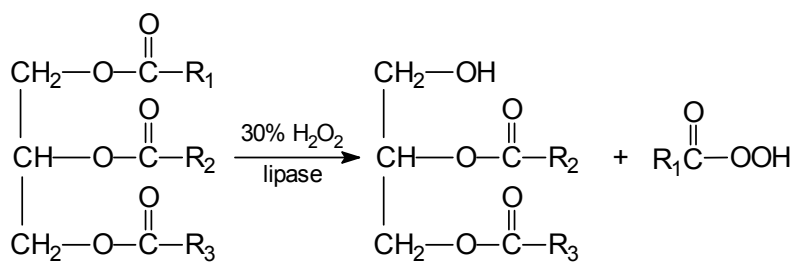

Scheme 4. Perhydrolysis of triglycerols.

Lipase B shows lower catalytic activity in the epoxidation of glycerides than in the process with alkyl esters of monocarboxylic acids [58]. The low hydrolytic activity towards triglycerides of long chain fatty acids is probably due to the narrow and deeply located active sites of the enzyme [60,61]. Lipase B are also the catalyst of triglycerides transesterification and hydrolysis. The product of epoxidation of oils containing unsaturated fatty acids is a mixture of epoxidized mono-, di-, triglycerides, glycerol and epoxidized free fatty acids [51,62,63].

Epoxidation of rapeseed, sunflower and linseed oils involves a maximum of $88 \%-95 \%$ of $C=C$ bonds [51-54,63]. Perhydrolysis of oils leads to the formation of peroxy fatty acids and monoand diglycerides. Their removal is practically impossible. The addition of free fatty acids (in a maximum amount up to $5 \%$ with respect to $C=C$ bonds in a given oil) to a given oil prevents or substantially restricts the amount of mono- and diglycerides. Perhydrolysis occurs, but the hydroxyl groups of glycerol, mono- and diglycerides are reesterified by the excess of free fatty acids. In this way, the reaction product contains only epoxidized triglycerides and epoxidized free fatty acids. Free fatty acids can be easily removed by alkaline washing. In most applications the presence of these by-products does not matter. Their amount in the post-reaction mixture is determined by the equilibrium of the three simultaneous reactions:

- hydrolysis of ester to alcohol and free acid,

- perhydrolysis of ester with hydrogen peroxide to alcohol and peroxy acid,

- oxidation of free fatty acid with hydrogen peroxide to peroxy acid.

Chemoenzymatic epoxidation is characterised by high chemo-, regio- and stereoselectivity [16]. Lipase immobilized on the adsorbent can be easily recycled.

\section{Technological Parameters of Chemoenzymatic Epoxidation}

A typical reaction system for a biocatalytic reaction is composed of the water layer containing hydrogen peroxide, organic layer containing a solvent, usually toluene, a vegetable oil or its alkyl ester and immobilised enzyme (solid phase) [26]. Chemoenzymatic epoxidation of soybean, rapeseed, linseed, corn, sunflower and olive oils has been best described. There is also substantial information on the epoxidation of oleic, linoleic, linolenic, erucic acids and alkyl esters thereof.

\subsection{Amount of Hydrogen Peroxide and Time of Reaction}

Orellana-Coca et al. have reported that the amount of hydrogen peroxide has the greatest influence on the rate of the reaction and the degree of epoxidation (conversion) [64,65]. An excess of hydrogen peroxide relative to the number of unsaturated bonds is necessary. This permits reaching full conversion of double bonds and compensation of hydrogen peroxide loss, caused by its decomposition at temperatures above $50^{\circ} \mathrm{C}$. The challenge is to shorten the reaction time. Too long a reaction time ( 6 to $12 \mathrm{~h}$ ) and excess of hydrogen peroxide lead to increased level of carboxylic peracids in the final product. Peracids could be a potential problem for reasons of safety and contamination of the final product. The reaction rate increased with increasing hydrogen peroxide concentration between $10-50 \mathrm{wt} \%$. However, it was accompanied with the enzyme inactivation. Linoleic acid was 
completely epoxidized when used at a concentration of $0.5-2.0 \mathrm{M}$ in toluene at $30^{\circ} \mathrm{C}$. In a solvent free medium the reaction was incomplete due to the formation of a solid or a highly viscous oily phase, which increased the resistance to mass transfer.

\subsection{The Effect of Process Temperature and Type of Solvent}

An increase in temperature to a value not exceeding $50^{\circ} \mathrm{C}$ also increases the rate of the reaction because it does not lead to hydrogen peroxide decomposition and enzyme inactivation. Törnvall et al. have performed chemoenzymatic epoxidations of unsaturated oleic and perpalmitic fatty acids in the presence of immobilized Candida antarctica lipase B [66]. Lipase B has been immobilized onto acrylic resin, in the presence of different solvents: toluene, water, $\mathrm{H}_{2} \mathrm{O}_{2}$, oleic acid, perpalmitic acid and epoxystearic acid, in the temperature range $20-60{ }^{\circ} \mathrm{C}$, and then its catalytic activity in the process of epoxidation was evaluated. Epoxystearic acid caused a slight enzyme deactivation at $50{ }^{\circ} \mathrm{C}$, in contrast to oleic acid and perpalmitic acid. Also a mixture of toluene and water did not cause deactivation of lipase $\mathrm{B}$ in the range $20-60{ }^{\circ} \mathrm{C}$ and in a $48 \mathrm{~h}$ period. The activity of lipase $\mathrm{B}$ was maintained in the presence of 6-12 M hydrogen peroxide at $20^{\circ} \mathrm{C}$, but at $60{ }^{\circ} \mathrm{C}$ it rapidly decreased. Also with increasing concentration of hydrogen peroxide the rate of lipase deactivation increased. Gradual addition of lipase B was particularly important for the processes carried out in higher temperatures and at the beginning of the process, before the water generated in the process could dilute the hydrogen peroxide. The activity of lipase decreased as a result of a too high concentration of $\mathrm{H}_{2} \mathrm{O}_{2}$ and a too high temperature $\left(60^{\circ} \mathrm{C}\right)$. Because of the exothermic character of epoxidation, this fact is of particular concern for the processes carried out on large scale. Toluene is the best stabiliser of lipase and it facilitates contact between the substrates and biocatalyst.

In the presence of catalytic amounts of lipase B, simultaneous esterification and epoxidation of oleic acid was also performed [67]. Higher degrees of esterification and epoxidation were obtained with n-octanol, $n$-hexanol, n-butanol than with ethanol and 2-propanol. The rate and yield of epoxidation were the highest in the reaction with 2-propyl oleate and lower with other alcohol esters. The esterification was relatively fast, like epoxidation of oleic acid and co-occurring alkyl ester. The main problem with the use of lipase B was a considerable decrease in its activity caused by the presence of concentrated hydrogen peroxide. Gradual addition of hydrogen peroxide also reduced the enzyme deactivation. The decrease in lipase B activity caused by the presence of alcohols was smaller than that caused by hydrogen peroxide, and the greatest in the presence of ethanol. Enzymatic synthesis of alkyl epoxystearate with employment of oleic acid is simpler and more energy saving than the classical method of epoxidation with peroxy acids (performic or peracetic acid). The former process does not need the use of additional solvents so the isolation of the main product is easier. High yields of epoxystearic acid and epoxystearic acid methyl ester have also been obtained by epoxidation of oleic acid or its methyl ester under solvent free conditions [68]. Bjőrkling et al. have confirmed a decrease in lipase B activity after a few cycles of epoxidation of alkenes [69]. In nonpolar solvents, toluene and hexane, this decrease was much slower.

High yield and rate of the reaction have been reported by Silva et al. in epoxidation of methyl oleate in the presence of hydrophilic ionic liquid and Aspergillus niger lipase [70]. A hydrophilic ionic liquid, butylmethylimidazolium tetrafluoroborate [bmi][BF 4 , allowed production of the epoxidized compound in $89 \%$ yield after the first hour of reaction. In the presence of hydrophobic butylmethyl-imidazolium hexafluorophosphate [bmi][ $\left.\mathrm{PF}_{6}\right]$ the yield was $67 \%$.

By enzymatic method, using the CALB catalyst immobilized on silica, excellent yields and selectivities of cis-methyl-9,10-epoxystearate were obtained by the epoxidation of methyl oleate [71]. The same yields were also obtained after a shorter reaction time as compared with the catalyst Novozym ${ }^{\circledR} 435$. However, the shortest reaction time were obtained during the epoxidation with hydrogen peroxide in the presence of bis-[3,5-bis(trifluoromethyl)diphenyl] as catalyst and 1,1,1,3,3,3-hexafluoroisopropanol as solvent (a nonenzymatic process). The shortest reaction time were obtained, but during the epoxidation with hydrogen peroxide in the presence 
of bis-[3,5-bis(trifluoromethyl)diphenyl] as catalyst and 1,1,1,3,3,3-hexafluoroisopropanol as solvent (nonenzymatic process).

\subsection{The Presence of Free Fatty Acids in Oils or Fatty Acids Esters}

$\mathrm{Lu}$ et al. have reported the highest epoxy oxygen group content in the epoxidation of soybean oil methyl esters in the presence of behenic and stearic acid [72]. The reaction was conducted at $0.001: 1 \mathrm{~mol} / \mathrm{g}$ ratio of free fatty acids to soybean oil methyl esters at $55{ }^{\circ} \mathrm{C}$ and $800 \mathrm{rpm}$ mixing speed. The input material was composed of $10 \mathrm{~g}$ esters, $0.3 \mathrm{~g}$ lipase, $50 \mathrm{~g}$ toluene, $14 \mathrm{~g} \mathrm{H}_{2} \mathrm{O}_{2}(35 \%$ concentration). For saturated and monounsaturated $\left(\mathrm{C}_{12}-\mathrm{C}_{18}\right)$ free fatty acids (FFA), the epoxy oxygen content increased with increasing carbon chain length of FFA. For branched-chain unsaturated FFA, the epoxy oxygen group content decreased in the presence of hydroperoxide and hydroxyl group of FFA. The epoxy oxygen group content also decreased with increasing number of double bonds in FFA.

The optimum parameters of the process of chemoenzymatic epoxidation of soybean oil in the presence of lipase B immobilised on acryl resin have been established by Vlček and Petrović [73]. They used soybean oil containing $8 \mathrm{wt} \%$ of oleic acid and they changed the lipase concentration in the range 2.1-20.8 wt \% relative to the oil content. A 35\% solution of $\mathrm{H}_{2} \mathrm{O}_{2}$ was introduced into a mixture of soybean oil, toluene and lipase (molar ratio $\mathrm{H}_{2} \mathrm{O}_{2} / \mathrm{C}=\mathrm{C}=2: 1$ ). The number of unsaturated bonds in the soybean oil molecule was $4.5 \mathrm{~mol} / \mathrm{mol}$. After increasing the lipase concentration to $4 \mathrm{wt} \%$ relative to the oil content, a fast increase in the conversion of unsaturated bonds with formation of epoxy groups took place. The concentration of lipase significantly affects the formation of epoxide groups. Having increased lipase B concentration to $20 \mathrm{wt} \%$, the conversion reached a stable level of $95-99 \mathrm{wt} \%$, after $4 \mathrm{~h}$ at $50{ }^{\circ} \mathrm{C}$. Conversion at a level of $40 \%$ was reached after $2 \mathrm{~h}$. Addition of free fatty acids was not necessary as they were present in soybean oil as a result of partial hydrolysis of ester bonds. The conversion of soybean oil at the level $80 \%$ was commonly achieved in the system without the presence of any fatty acid.

Sun et al. have established the optimum technological parameters of corn oil epoxidation using $\mathrm{H}_{2} \mathrm{O}_{2}$ as an oxygen donor and stearic acid as an active oxygen carrier [74]. They obtained a relative conversion to oxirane of $85.3 \%$ and epoxy oxygen group content $5.8 \%$. The optimum parameters found by these authors were: temperature $35{ }^{\circ} \mathrm{C}$, amount of stearic acid $28 \%$ in relation to corn oil, mole ratio of $\mathrm{H}_{2} \mathrm{O}_{2} / \mathrm{C}=\mathrm{C}$ bonds 2.7:1, reaction time $10 \mathrm{~h}$. The impact of these parameters decreased in the order: amount of stearic acid $>$ temperature $\approx$ molar ratio of $\mathrm{H}_{2} \mathrm{O}_{2} / \mathrm{C}=\mathrm{C}$ bonds $>$ reaction time.

Sun et al. have studied also chemoenzymatic epoxidation of Sapindus mukorossi seed oil [75]. Hydrogen peroxide and stearic acid were used as epoxidizing agents. The iodine number of the oil was $84.8 \mathrm{~g} / 100 \mathrm{~g}$ and the oil contained [wt \%]: oleic acid 51.0, linoleic acid 6.6, linolenic acid 1.1 and eicosanoic acid 23.1. These authors showed that stearic acid enhanced the enzymatic epoxidation of oil. The content of epoxy oxygen groups in the obtained product was $4.6 \%$. The optimised epoxidation conditions were as follows: temperature $50{ }^{\circ} \mathrm{C}$, $4: 1$ molar ratio of $\mathrm{H}_{2} \mathrm{O}_{2} / \mathrm{C}=\mathrm{C}$, reaction time $7.0 \mathrm{~h}$, the amount of lipase B $2.0 \mathrm{wt} \%$ relative to the oil weight. Relative conversion to oxirane was $90.2 \%$. It results from these studies that the epoxidation of unsaturated fatty acids with hydrogen peroxide in the presence of simple carboxylic acids as well as by chemoenzymatic method proceeds faster than the epoxidation of vegetable oils. These research indicates that the epoxidation of unsaturated fatty acids both by the use hydrogen peroxide in the presence of simple carboxylic acids and chemoenzymatic are rapidly than the epoxidation of vegetable oils.

Schneider et al. have reported the optimal parameters of epoxidation of methyl esters of sunflower oil with lipase $\mathrm{B}$ and aqueous $\mathrm{H}_{2} \mathrm{O}_{2}$ in the presence and absence of an acyl donor (octanoic acid) [76]. The biphasic system $\mathrm{CH}_{2} \mathrm{Cl}_{2} / \mathrm{H}_{2} \mathrm{O}$ comprised $30 \%$ hydrogen peroxide and lipase $\mathrm{B}$. The use of biphasic system for reduction of lipase inactivation was proposed as an alternative solution, because the enzyme remains protected in the aqueous phase. This process begins with perhydrolysis of methyl esters derived from sunflower oil, under mild conditions, catalysed by 
lipase. The conversion of unsaturated bonds reaches $99 \%$ both in the biphasic $\left(\mathrm{CH}_{2} \mathrm{Cl}_{2} / \mathrm{H}_{2} \mathrm{O}\right.$ and monophasic $\left(\mathrm{CH}_{2} \mathrm{Cl}_{2}\right)$ systems. The presence of caprylic acid as a peracids precursor is of crucial importance. The main products are mono- and diepoxystearates. The best technological parameters were found to be as follows: $30{ }^{\circ} \mathrm{C}$, reaction time $16 \mathrm{~h}, 10 \mathrm{mmol}$ octanoic acid in relation to $1 \mathrm{~g}$ of the oil, $1 \mathrm{~mL} \mathrm{30 \%} \mathrm{H}_{2} \mathrm{O}_{2}$ in relation to $1 \mathrm{~g}$ of the oil, $100 \mathrm{mg}$ lipase $\mathrm{B}, 6 \mathrm{~mL} \mathrm{CH}_{2} \mathrm{Cl}_{2}$ and $5 \mathrm{ml}$ of water. Lipase B was reused 10 times in successive experiments at $24 \mathrm{~h}$ intervals, without a significant loss of activity.

\subsection{Effect of Simultaneous Changes in a Few Parameters}

Chemoenzymatic epoxidation of linseed oil to obtain epoxyglycerides of different content of oxygen has been studied by López Téllez et al. [77]. On changing the temperature, amount of hydrogen peroxide of 30 or $50 \mathrm{wt} \%$ concentration and the amount of lipase B, the epoxidized oils demonstrated epoxidation degrees ranging from $8 \%$ to $54 \%$. The absence of side reactions was confirmed by FTIR and Raman spectroscopy. Analysis of ${ }^{1} \mathrm{H}-\mathrm{NMR}$ data provided a linear relation between the number of double bonds and the epoxide number.

Epoxidation reactions obtaining methyl epoxyricinoleate in the presence of lipase B have been studied by Kazariya and Matsumura for [78]. Lipase and hydrogen peroxide (30 wt \%) were added to a solution of methyl ricinoleate in toluene, and the mixture was stirred at room temperature for $24 \mathrm{~h}$. After separation, methyl epoxyricinoleate was polycondensed to polyepoxyricinoleate with an average molecular weight $\mathrm{M}_{\mathrm{w}}=272,000$.

Besides epoxidation of fatty acids and their derivatives, lipase was used for epoxidation of phenolic compounds for the synthesis of phenolic epoxy prepolymers (Aouf et al. [79]). Urea hydrogen peroxide was used instead of hydrogen peroxide, and no significant differences in deactivation of lipase B were observed [67].

De Abreu Corrêa et al. have reported the following optimum parameters of epoxidation of oleic acid catalysed by PSCI-Amano lipase from Burkholderia cepacia immobilized on ceramic: $55{ }^{\circ} \mathrm{C}, 10 \%$ content of enzyme, $0.2 \%$ concentration of hydrogen peroxide, reaction time $3 \mathrm{~h}$, stirring speed $150 \mathrm{rpm}$ [27]. Under these conditions the epoxidation yield was close to $88 \%$, while the conversion and selectivity of epoxidation of rapeseed, sunflower, soybean and linseed oils reached over $90 \%[52,53]$. In the process of epoxidation of linseed oil, the content of oxirane oxygen was $9.9 \%$, which is close to the theoretical value. High content of oxirane oxygen is especially desirable when the oil is to be used as a plasticizer and plastic stabilizer. When epoxidized oils are used as paint and varnish solvents, it is important that they show low viscosity, appropriate iodine number and oxirane oxygen contents. These properties should be similar to those found in natural oils containing epoxy groups, such as vernonia oil (viscosity $112 \mathrm{mP}$ ). A product of similar properties was obtained as a result of epoxidation of a mixture of sunflower and linseed oil (molar ratio 3:1). At a conversion of $40 \%$, the epoxidized synthetic oil obtained showed properties closest to those of the natural vernonia oil (similar content of oxirane oxygen, epoxide number and viscosity). The difference between the two oils was in chemical structure; the synthetic product did not contain vernolic acid whose presence determined the oil properties and had a different spatial structure.

Chemoenzymatic epoxidation of linseed oil in a recirculating reactor with separation of immobilized lipase B from the water solution of hydrogen peroxide, has been reported by Hilker et al. [26]. This solution permitted a reduction of the deactivation of immobilized lipase dispersed within the organic phase, as the lipase contact with the aqueous hydrogen peroxide solution was limited. In order to achieve saturation with $\mathrm{H}_{2} \mathrm{O}_{2}$, the organic layer was passed through the aqueous layer containing $\mathrm{H}_{2} \mathrm{O}_{2}$ in a bubble column. The membrane was quickly flushed by reversing the direction of the pump to prevent blocking. The actual epoxidizing agent was perstearic acid. On the basis of kinetic studies it was determined that the stability and activity of the enzyme depended mainly on the reaction temperature and $\mathrm{H}_{2} \mathrm{O}_{2}$ concentration. 


\section{Stability and Inactivation of Lipase B}

Deactivation of lipase is the main problem in chemoenzymatic epoxidation of unsaturated compounds. High price and limited lipase use time make the process and its applications less economically advantageous than other types of epoxidation processes, especially the in situ peracid epoxidation. In batch processes the number of recirculations of a catalyst is also limited by the impossibility of catalyst regeneration. Warwel et al. have reported that on epoxidation of unsaturated fatty acids the were able to extend the lipase activity up to 15 cycles thanks to the use of toluene as a solvent [54]. The duration of one cycle was $8 \mathrm{~h}$. Unfortunately, the lipase activity decreased to $75 \%$ of the initial one. To increase the lipase stability and number of use cycles, an excess of unsaturated compound with respect to hydrogen peroxide was tested. Hydrophobic solvents are generally preferred for lipase catalysed reactions. The negative influence of solvent polarity on lipase activity and stability seems indeed to be due to competition between the solvent and enzymatic protein for water [80]. Such a competition leads to the state of the protein hydration which is crucial for its activity. Hydrophobic solvents are not always used for lipase catalysed reactions involving polar substrates such as phenolic compounds or amino acids [81]. Solvents with intermediate polarities are also used like for example: tert-butyl alcohol [82], acetone [83], 2-methyl-2-butanol [84], methylene chloride [76], etc.

Decreases in lipase B activity in subsequent alkene epoxidation processes have also been reported by other authors [69]. The decrease was the slowest in the presence of nonpolar solvents, toluene and hexane. Optimisation of the technological parameters of epoxidation permitted extension of the time of lipase activity and its use [68]. The greatest impact on reduction of lipase stability and activity has a high concentration of hydrogen peroxide (above $12 \mathrm{M}$ at $20^{\circ} \mathrm{C}$ ) and temperatures above $50{ }^{\circ} \mathrm{C}$ [66]. For this reason, diluted solutions of $\mathrm{H}_{2} \mathrm{O}_{2}$ are used and these solutions are dosed slowly. Water is also a good solvent for lipases. In biphasic aqueous-hydrophobic media this property allows one to increase the yield of epoxide. In this way at least one of the reactants is mainly water soluble and another one is hydrophobic. This allows easier solubilisation of polar and nonpolar reactants $[81,82]$. The most important technological parameters of chemoenzymatic epoxidation of vegetable oils, free fatty acids and their esters are presented in Table 1.

\section{Conclusions}

The only method of epoxidation applied on the industrial scale is that employing peracids either prepared in a separate step or generated in situ. Because of the risks related to handling peracids, the in situ method is preferred for industrial scale epoxidation of triglycerides [52]. In chemoenzymatic epoxidation the highest yields and transformation selectivities to epoxidized vegetable oils have been achieved in the presence of Candida antarctica lipase B. Although other enzymes have been also found able to catalyse epoxidations, e.g., diiron-centre oxygenases, lipoxygenases, peroxygenases, they are less effective. The main problem with chemoenzymatic epoxidation at large-scale is the deactivation of the expensive lipase B enzyme. The deactivation is particularly effective at elevated concentrations of hydrogen peroxide, too high temperatures and in the presence of alcohols, especially ethanol. The effective working time of the catalyst also depends on other process parameters, so the impact of technological parameters on the time of lipase use has been also studied. The rate of epoxidation increases with increasing process temperature, and in a certain range of initial hydrogen peroxide concentrations (10-50 wt \%) and amount of lipase. Other important parameters are the amount of solvent (usually toluene), molar ratio of hydrogen peroxide to unsaturated bonds, type of oil or unsaturated acid or alkyl ester of unsaturated acid. In contrast to the classical epoxidation processes based on the use of peroxy acids, in the enzymatic processes the reduction in yield is a result of a lower conversion (lower degree of transformation of unsaturated bonds). It is not a consequence of a lower selectivity transformation of unsaturated bonds to epoxy compounds. The epoxide ring opening side reactions do not occur in the process or they are of minor importance. The reason is that in chemoenzymatic epoxidation there is no need to use strong mineral acids $\left(\mathrm{H}_{2} \mathrm{SO}_{4}, \mathrm{HNO}_{3}\right.$, 
$\mathrm{H}_{3} \mathrm{PO}_{4}$ ) that catalyse the formation of peroxyacid but at the same time induce oxirane ring opening. The absence of a low-molecular carboxylic acid (acetic or formic) means that no hydroxyesters are formed. Chemoenzymatic epoxidation shows the highest selectivity from among the epoxidation methods mentioned and moreover it is highly stereoselective. In the process of chemoenzymatic epoxidation of vegetable oils, the highest efficiency (also conversion of unsaturated bonds) and the reaction rates were achieved by introduction, prior to epoxidation, of small amounts of a higher carboxylic acid (up to $5 \%$ relative to the number of $\mathrm{C}=\mathrm{C}$ bonds) or a mixture of acids, preferably those already present in the oil.

Due to the enhanced decomposition of concentrated solutions of hydrogen peroxide and a possibility of explosive decomposition of these solutions if their concentration exceeds $60 \mathrm{wt} \%$, water solutions of hydrogen peroxide at a concentration of $30 \mathrm{wt} \%$ are usually used. Because of inactivation of lipase B the hydrogen peroxide concentration in the reaction medium usually does not exceed $1 \mathrm{wt} \%$. As yet the highest stability of lipase B has been obtained on epoxidation of unsaturated fatty acids in the presence of peroxyacids generated in situ.

The main benefits of chemoenzymatic epoxidation of vegetable oils, unsaturated fatty acids and their alkyl esters include:

- mild reaction conditions, $25-55{ }^{\circ} \mathrm{C}$,

- neutral $\mathrm{pH}$ of the reaction mixture,

- possibility of carrying out the process without solvent, which facilitates product separation,

- formation of stable carboxylic peroxyacids under the effect of hydrogen peroxide and in the presence of the enzyme applied; when vegetable oils are used - the above formation also takes place as a result of perhydrolysis,

- possibility of useing immobilized lipase as a biocatalyst (native enzymes can occur in the form of liquids or solid powders),

- high chemo-, region- and stereoselectivity,

- often high conversion of unsaturated bonds in vegetable oils, unsaturated fatty acids and fatty acids esters,

- small contribution or the absence of side reactions (high selectivity),

- the method is safe and environmentally friendly.

The main disadvantage is the high dilution of the reaction solution. Based on the literature review it can be concluded that a large variety of epoxidation methods and technological parameters exist. This study reveals the advantages and distinct efficiency of chemoenzymatic methods. At the same time it allows us to note the need for the individual establishment of technological parameters for a given vegetable oil, unsaturated fatty acid or fatty acid alkyl ester. 
Table 1. Technological parameters chemoenzymatic epoxidation of vegetable oils, free fatty acids and their alkyl esters

\begin{tabular}{|c|c|c|c|c|c|c|c|c|c|}
\hline Substrate & $\begin{array}{c}\text { Amount of } \\
\text { Free Fatty Acid }\end{array}$ & $\begin{array}{c}\mathrm{H}_{2} \mathrm{O}_{2} / \mathrm{C}=\mathrm{C} \\
\text { Molar Ratio } \\
\text { mol/mol }\end{array}$ & $\begin{array}{c}\text { Temperature } \\
\left({ }^{\circ} \mathrm{C}\right)\end{array}$ & Catalyst (wt \%) & Solvent & Mixing (rpm) & $\begin{array}{l}\text { Reaction } \\
\text { Time (h) }\end{array}$ & Conversion (\%) & Reference \\
\hline Soybean oil & $\begin{array}{c}\text { Oleic acid } 8 \mathrm{wt} \\
\% / \mathrm{SO}\end{array}$ & $2: 1$ & 50 & $\begin{array}{c}\text { Lipase } \\
\text { B/acrylic resin } \\
\end{array}$ & Toluene & 350 & 24 & 95-99 & [73] \\
\hline $\begin{array}{l}\text { Soybean oil methyl } \\
\text { esters IN }=133.0 \\
\mathrm{~g} / 100 \mathrm{~g} \text { oil }\end{array}$ & $\begin{array}{c}\text { FFA } / \mathrm{SME}= \\
0.001: 1 \mathrm{~mol} / \mathrm{g}\end{array}$ & $\underset{\mathrm{SME}}{1.4 \mathrm{~g} \mathrm{H}_{2} \mathrm{O}_{2} / 1 \mathrm{~g}}$ & 55 & $\begin{array}{c}\text { 3\% Lipase } \\
\text { B/acrylic resin }\end{array}$ & $\begin{array}{c}5: 1 \mathrm{~g} / \mathrm{g} \\
\text { toluene/esters }\end{array}$ & 800 & $10-12$ & 98 & [72] \\
\hline $\begin{array}{l}\text { Sunflower oil } \\
\text { methyl esters }\end{array}$ & $\begin{array}{c}\text { Octanoic } \\
\text { acid } / \text { esters }=10 \\
\mathrm{mmol} / \mathrm{g}\end{array}$ & not specified & 30 & $\begin{array}{l}\text { Lipase B } 10 \\
\text { times was } \\
\text { reused }\end{array}$ & $\begin{array}{c}\mathrm{CH}_{2} \mathrm{Cl}_{2} \\
\mathrm{CH}_{2} \mathrm{Cl}_{2}-\mathrm{H}_{2} \mathrm{O}\end{array}$ & not specified & 16 & 99 & [76] \\
\hline $\begin{array}{l}\text { Oleic acid or ethyl } \\
\text { oleate }\end{array}$ & not specified & $\begin{array}{c}\mathrm{H}_{2} \mathrm{O}_{2} \\
\text { concentration } \\
\text { in solution } 0.2 \\
\text { wt } \% \\
\end{array}$ & 55 & $\begin{array}{c}10 \% \text { Amano } \\
\text { lipase from } \\
\text { Burkholderia } \\
\text { cepacia }\end{array}$ & Ethyl acetate & 150 & 3 & 88 & [27] \\
\hline $\begin{array}{l}\text { Safindus muko } \\
\text { rossi seed oil IN = } \\
84.8 \mathrm{~g} / 100 \mathrm{~g} \text { oil }\end{array}$ & Stearic acid & $4: 1$ & 50 & $\begin{array}{c}2 w t \% \text { Lipase } \\
\text { B/oil }\end{array}$ & Toluene & 800 & 7 & 90.2 & [75] \\
\hline $\begin{array}{l}\text { Rapeseed methyl } \\
\text { esters }\end{array}$ & $\begin{array}{c}\text { FFA are formed } \\
\text { by ester } \\
\text { hydrolysis }\end{array}$ & $\begin{array}{c}\mathrm{H}_{2} \mathrm{O}_{2} \\
\text { concentration } \\
\text { in water } \\
\text { phase-15 M }\end{array}$ & 40 & $\begin{array}{c}3 \text { wt \% Lipase } \\
\text { B/RME }\end{array}$ & Solvent-free & 450 & 14 & 83 & [85] \\
\hline
\end{tabular}


Acknowledgments: No special funding for this work.

Author Contributions: E.M., K.M., and M.K. wrote the paper; M.K. drafted and revised the paper. All authors read and approved the final manuscript.

Conflicts of Interest: The authors declare no conflict of interest.

\section{References}

1. Muturi, P.; Wang, D.; Dirlikov, S. Epoxidized vegetable oils as reactive diluents. Comparison of vernonia, epoxidized soybean and epoxidized linseed oils. Prog. Org. Coat. 1994, 25, 85-94. [CrossRef]

2. Adhvaryu, A.; Erhan, S.Z. Epoxidized soybean oil as a potential source of high-temperature lubricants. Ind. Crops Prod. 2002, 15, 247-250. [CrossRef]

3. Campanella, A.; Rustoy, E.; Baldessaria, A.; Baltanas, M.A. Lubricants from chemically modified vegetable oils. Bioresour. Technol. 2010, 101, 245-254. [CrossRef] [PubMed]

4. Crivello, J.V.; Narayan, R.; Sternstein, S.S. Photoinitiated cationic polymerization of naturally occurring epoxidized triglycerides. J. Appl. Polym. Sci. 1997, 64, 2073-2087. [CrossRef]

5. Fantoni, L.; Simoneau, C. European survey of contamination of homogenized baby food by epoxidized soybean oil migration from plasticized PVC gaskets. Food Addit. Contam. 2003, 20, 1087-1096. [CrossRef] [PubMed]

6. Soucek, M.D.; Johnson, A.H.; Wegner, J.M. Ternary evaluation of UV-curable seed oil inorganic/organic hybrid coatings using experimental design. Prog. Org. Coat. 2004, 51, 300-311. [CrossRef]

7. Rosli, W.D.; Kumar, R.N.; Mek Zah, S.; Hilmi, M.M. UV radiation curing of epoxidized palm oil-cycloaliphatic diepoxide system induced by cationic photoinitiator for surface coating. Eur. Polym. J. 2003, 39, 593-600. [CrossRef]

8. Shaker, N.O.; Kandeel, E.M.; Badr, E.E.; El-Sawy, M.M. Syntheses and properties of renewable environment-friendly epoxy resins for surface coatings. J. Dispers. Sci. Technol. 2008, 29, 421-425. [CrossRef]

9. Thames, S.F.; Yu, H.B. Cationic UV-cured coatings of epoxide-containing vegetable oils. Surf. Coat. Technol. 1999, 115, 2008-2014. [CrossRef]

10. Wool, R.; Küsefoglu, S.; Palmese, G.; Khot, S.; Zhao, R. High Modulus Polymers and Composites from Plant Oils. USA Patent 6121 398, 19 September 2000.

11. Hwang, H.; Adhvaryu, A.; Erhan, S.Z. Preparation and properties of lubricant base stocks from epoxidized soybean oil and 2-ethylhexanol. J. Am. Oil Chem. Soc. 2003, 80, 811-815. [CrossRef]

12. Hwang, H.; Erhan, S.Z. Modification of epoxidized soybean oil for lubricant formulations with improved oxidative stability and low pour point. J. Am. Oil Chem. Soc. 2001, 78, 1179-1184. [CrossRef]

13. Wu, X.; Zhang, X.; Yang, S.; Chen, H.; Wang, D. The study of epoxidized rapeseed oil used as a potential biodegradable lubricant. J. Am. Oil Chem. Soc. 2000, 77, 561-563. [CrossRef]

14. Wirpsza, Z. Polyurethanes: Chemistry, Technology, Application; WNT: Warsaw, Poland, 1991.

15. Czuprynski, B. Zagadnienia z Chemii i Technologii Poliuretanów; Kazimierz Wielki University in Bydgoszcz: Bydgoszcz, Poland, 2004.

16. Metzger, J.O.; Bornscheuer, U.T. Lipids as renewable resources: Current state of chemical and biotechnological conversion and divesification. Appl. Microbiol. Biot. 2006, 71, 13-22. [CrossRef] [PubMed]

17. Monteavaro, L.L.; da Silva, E.O.; Costa, A.P.O.; Samios, D.; Gerbase, A.E.; Petzhold, C.L. Polyurethane networks from formiated soy polyols: Synthesis and mechanical characterization. J. Am. Oil Chem. Soc. 2005, 82, 365-371. [CrossRef]

18. Miyagawa, H.; Mohanty, A.K.; Drzal, L.T.; Misra, M. Nanocomposites from biobased epoxy and single-wall carbon nanotubes: Synthesis, and mechanical and thermophysical properties evaluation. Nanotechnology 2005, 16, 118-124. [CrossRef]

19. Khot, S.N.; Lascala, J.J.; Can, E.; Moyre, S.S.; Wiliams, G.I.; Palmese, G.R.; Kusefoglu, S.H.; Wool, P. Development and Application of Triglyceride-Based Polymers and Composites. J. Appl. Polym. Sci. 2001, 82, 703-723. [CrossRef]

20. Hermandez-Lopez, S.; Vigueras-Santiago, E.; Marcado-Posadas, J.; Sanchez-Mendieta, V. Electricial properties of acrylated-epoxidized soybean oil polymers-based composites. Adv. Technol. Mater. Mat. Process. J. 2006, 8, 214-219. 
21. Gerbase, A.E.; Petzhold, C.L.; Costa, A.P.O. Dynamic mechanical and thermal behavior of epoxy resins based on soybean oil. J. Am. Oil Chem. Soc. 2002, 79, 792-802. [CrossRef]

22. Biswas, A.; Adhvaryu, A.; Gordon, S.H.; Erhan, S.Z.; Willet, J.L. Synthesis of diethylamine-functionalized soybean oil. J. Agric. Food Chem. 2005, 53, 9485-9490. [CrossRef] [PubMed]

23. La Scala, J.; Wool, R.P. Property analysis of triglyceride-based thermosets. Polymer 2005, 46, 61-69. [CrossRef]

24. Hiroaki, M.; Robert, J.J.; Amar, K.M.; Manjusri, M.; Lawrence, T.D. Biobased epoxy/clay nanocomposites as a new matrix for CFRP. Compos. Part A Appl. Sci. Manuf. 2006, 37, 54-62.

25. Xu, J.Y.; Liu, Z.S.; Erhan, S.Z.; Carriere, C.J. A potential biodegradable rubber-Viscoelastic properties of a soybean oil-based composite. J. Am. Oil Chem. Soc. 2002, 79, 593-596. [CrossRef]

26. Hilker, I.; Bothe, D.; Prüss, J.; Warnecke, H.J. Chemoenzymatic epoxidation of unsaturated plant oils. Chem. Eng. Sci. 2001, 56, 427-432. [CrossRef]

27. De Abrêu, F.; Sutili, F.K.; Miranda, L.S.M.; Leite, S.G.F.; de Souza, R.M.A.; Leal, I.C.R. Epoxidation of oleic acid catalyzed by PSCI-Amano lipase optimized by experimental design. J. Mol. Catal. B Enzym. 2012, 81, 7-11.

28. Goud, V.V.; Patwardhan, A.V.; Pradhan, N.C. Studies on the epoxidation of mahua oil (Madhumica Indica) by hydrogen peroxide. Bioresour. Technol. 2006, 97, 1365-1371. [CrossRef] [PubMed]

29. Salimon, J.; Salih, N. Improved low temperature properties of 2-ethylhexyl-9(10)-hydroxy10(9)-Acyloxystearate derivatives. Eur. J. Sci. Res. 2009, 31, 583-591.

30. Campanella, A.; Fontanini, C.; Baltanas, M.A. High yield epoxidation of fatty acid methyl esters with performic acid generated in situ. Chem. Eng. J. 2008, 144, 466-475. [CrossRef]

31. Scala, J.L.; Wool, R.P. Effect of FA Composition on epoxidation kinetics of TAG. J. Am. Oil Chem. Soc. 2002, 79, 373-378. [CrossRef]

32. Goud, V.V.; Pradhan, N.C.; Patwardhan, A.V. Epoxidation of karanja (Pongamia glabra) oil by $\mathrm{H}_{2} \mathrm{O}_{2}$. J. Am. Oil Chem. Soc. 2006, 83, 635-640. [CrossRef]

33. Sinadovic-Fiser, S.; Jankovic, M.; Petrovic, Z.S. Kinetics of in situ epoxidation of soybean oil in bulk catalyzed by ion exchange resin. J. Am. Oil Chem. Soc. 2001, 78, 725-731. [CrossRef]

34. Goud, V.V.; Patwardhan, A.V.; Dinda, S.; Pradhan, N.C. Epoxidation of karanja (Pongamia glabra) oil catalyzed by acidic ion exchange resin. Eur. J. Lipid Sci. Technol. 2007, 109, 575-584. [CrossRef]

35. Meshram, P.D.; Puri, R.G.; Patil, H.V. Epoxidation of wild safflower (Carthamus oxyacantha) oil with peroxy acid in presence of strongly acidic cation exchange resin IR-122 as catalyst. Int. J. ChemTech Res. 2011, 3, 3-7.

36. Gurbanov, M.S.; Chalabiev, Ch.A.; Mamedov, B.A.; Efendiev, A.A. Epoxidation of soybean oil in the course of cooxidation with hydrogen peroxide in the presence of propanoic acid and chlorinated KU-2 8 cation exchanger. Russ. J. Appl. Chem. 2005, 78, 1678-1681. [CrossRef]

37. Mungroo, R.; Pradhan, N.C.; Goud, V.V.; Dalai, A.K. Epoxidation of canola oil with hydrogen peroxide catalyzed by acidic ion exchange resin. J. Am. Oil Chem. Soc. 2008, 85, 887-896. [CrossRef]

38. Goud, V.V.; Patwardhan, A.V.; Dinda, S.; Pradhan, N.C. Kinetics of epoxidation of jatropha oil with peroxyacetic and peroxyformic acid catalysed by acidic ion exchange resin. Chem. Eng. Sci. 2007, 62, 4065-4076. [CrossRef]

39. Guidotti, M.; Ravasio, N.; Psaro, R.; Gianotti, E.; Coluccia, S.; Marchese, L. Epoxidation of unsaturated FAMEs obtained from vegetable source over Ti(IV)-grafted silica catalysts: A comparison between ordered and non-ordered mesoporous materials. J. Mol. Catal. A: Chem. 2006, 250, 218-225. [CrossRef]

40. Blayo, A.; Gandini, A.; le Nest, J.F. Chemical and rheological characterizations of some vegetable oils derivatives commonly used in printing inks. Ind. Crops Prod. 2001, 14, 155-167. [CrossRef]

41. Gurbanov, M.S.; Mamedov, B.A. Epoxidation of flax oil with hydrogen peroxide in a conjugate system in the presence of acetic acid and chlorinated cation exchanger KU-2 $\times 8$ as catalyst. Russ. J. Appl. Chem. 2009, 82, 1483-1487. [CrossRef]

42. Poli, E.; Clacens, J.M.; Barrault, J.; Pouilloux, Y. Solvent-free selective epoxidation of fatty esters over a tungsten-based catalyst. Catal. Today 2009, 140, 19-22. [CrossRef]

43. Benanibaa, M.T.; Belhaneche-Bensemrab, N.; Gelbard, G. Kinetics of tungsten-catalyzed sunflower oil epoxidation studied by ${ }^{1}$ H-NMR. Eur. J. Lipid Sci. Technol. 2007, 109, 1187-1193. [CrossRef] 
44. Campanella, A.; Baltanas, M.A.; Capel-Sanchez, M.C.; Campos-Martin, J.M.; Fierro, J.L.G. Soybean oil epoxidation with hydrogen peroxide using an amorphous $\mathrm{Ti} / \mathrm{SiO}_{2}$ catalyst. Green Chem. 2004, 6, 330-334. [CrossRef]

45. Campanella, A.; Baltanas, M.A. Degradation of the oxirane ring of epoxidized vegetable oils in a liquid-liquid-solid heterogeneous reaction system. Chem. Eng. Process. 2007, 46, 210-221. [CrossRef]

46. Rios, L.A.; Weckes, P.; Schuster, H.; Hoelderich, W.F. Mesoporous and amorphous Ti-silicas on the epoxidation of vegetable oils. J. Catal. 2005, 232, 19-26. [CrossRef]

47. Ye, X.; Jiang, P.; Zhang, P.; Dong, Y.; Jia, Ch.; Zhang, X.; Xu, H. Novel Ti and mesoporous molecular sieves: Synthesis, characterization and catalytic activity in the epoxidation of vegetable oil. Catal. Lett. 2010, 137, 88-93. [CrossRef]

48. Du, G.; Tekin, A.; Hammond, E.G.; Woo, L.K. Catalytic epoxidation of methyl linoleate. J. Am. Oil Chem. Soc. 2004, 4, 477-480. [CrossRef]

49. Gerbase, A.E.; Gregorio, J.R.; Martinelli, M.; Brasil, M.C.; Mendes, N.F. Epoxidation of soybean oil by the methyltrioxorenium $\mathrm{CH}_{2} \mathrm{Cl}_{2} / \mathrm{H}_{2} \mathrm{O}_{2}$ catalytic biphasic system. J. Am. Oil Chem. Soc. 2002, 79, 179-181. [CrossRef]

50. Sepulveda, J.S.; Teixera, M.; Schuchardt, U. Alumina catalyzed epoxidation of unsaturated fatty esters with hydrogen peroxide. Appl. Catal. A Gen. 2007, 318, 213-217. [CrossRef]

51. Rüsch gen. Klaas, M.; Warwel, S. Chemoenzymatic epoxidation of unsaturated fatty acid esters and plant oils. J. Am. Oil Chem. Soc. 1996, 73, 1453-1457. [CrossRef]

52. Rüsch gen. Klaas, M.; Warwel, S. Complete and partial epoxidation of plant oils by lipase-catalyzed perhydrolysis. Ind. Crop Prod. 1999, 9, 125-132. [CrossRef]

53. Rüsch gen. Klaas, M.; Warwel, S. Lipase-catalysed preparation of peroxy acids and their use for epoxidation. J. Mol. Catal A: Chem. 1997, 117, 311-319. [CrossRef]

54. Warwel, S.; Rüsch gen. Klaas, M. Chemoenzymatic epoxidation of unsaturated carboxylic acids. J. Mol. Catal. B Enzym. 1995, 1, 29-35. [CrossRef]

55. Dinda, S.; Patwardhan, A.V.; Goud, V.V.; Pradhan, N.C. Epoxidation of cottonseed oil by aqueous hydrogen peroxide catalysed by liquid inorganic acids. Bioresour. Technol. 2008, 99, 3737-3744. [CrossRef] [PubMed]

56. Joseph, R.; Alex, R.; Vinod, V.S.; Premalatha, C.K.; Kuriakose, B. Studies on epoxidized rubber seed oil as plasticizer for acrylonitrile butadiene rubber. J. Appl. Polym. Sci. 2003, 89, 668-673. [CrossRef]

57. Okieimen, F.E.; Bakare, O.I.; Okieimen, C.O. Studies on the epoxidation of rubber seed oil. Ind. Crop Prod. 2002, 15, 139-144. [CrossRef]

58. Bjőrkling, F.; Frykman, H.; Goldtfredsen, S.E.; Kirk, O. Lipase-catalyzed synthesis of peroxycarboxylic acids and lipase-mediated oxidations. Tetrahedron 1992, 48, 4587-4592. [CrossRef]

59. Yadav, G.D.; Devi, K.M. Enzymatic synthesis of perlauric acid using Novozym ${ }^{\circledR} 435$. BioChem. Eng. J. 2002, 10, 93-101. [CrossRef]

60. Martinelle, M. Lipases from Candida antarctica and Humicola Lanuginosa-Structure-Activity Relationships and Applied Catalysis; Tekniska högsk: Stockholm, Sweden, 1995.

61. Biermann, U.; Friedt, W.; Lang, S.; Lühs, W.; Machmüller, G.; Metzger, J.O.; Rüsch gen. Klaas, M.; Schäfer, H.J.; Schneider, M.P. New synthesis with oils and fats as renewable raw materials for the chemical industry. Angew. Chem. Int Ed. 2000, 39, 2206-2224. [CrossRef]

62. Uppenberg, J.; Hansen, N.T.; Patkar, S.; Jones, T.A. The sequence, crystal structure determination and refinement of two crystal forms of lipase B from Candida antarctica. Structure 1994, 2, 293-308. [CrossRef]

63. Tiran, C.; Lecomte, J.; Dubreucq, E.; Villeneuve, P. Chemoenzymatic epoxidation of fatty compounds-Focus on processes involving a lipase-catalyzed perhydrolysis step. OCL 2008, 15, 179-183. [CrossRef]

64. Orellana-Coca, C.; Camocho, S.; Adlercreutz, D.; Mattiasson, B.; Hatti-Kaul, R. Chemoenzymatic epoxidation of linoleic acid: Parameters influencing the reaction. Eur. J. Lipid Sci. Technol. 2005, 107, 864-870. [CrossRef]

65. Abdullah, B.M.; Salimon, J. Epoxidation of vegetable oils and fatty acids: Catalyst methods and advantages. J. Appl. Sci. 2010, 10, 1545-1553.

66. Törnvall, U.; Orellana-Coca, C.; Hatti-Kaul, R.; Adlercreutz, D. Stability of immobilized Candida antarctica lipase B during chemoenzymatic epoxidation of fatty acids. Enzyme Microbial. Technol. 2007, 40, 447-451. [CrossRef] 
67. Orellana-Coca, C.; Billakanti, J.M.; Mattiasson, B.; Htti-Kaul, R. Lipase mediated simultaneous esterification and epoxidation of oleic acid for the production of alkylepoxystearates. J. Mol. Catal. B Enzym. 2007, 44, 133-137. [CrossRef]

68. Orellana-Coca, C.; Törnvall, U.; Adler-Creutz, D.; Mattiasson, B.; Hatti-Kaul, R. Chemoenzymatic epoxidation of oleic acid and methyl oleate in solvent-free medium. Biocatal. Biotransform. 2005, 23, 431-437. [CrossRef]

69. Bjőrkling, F.; Gadtfredsen, S.E.; Kirk, O. Lipase mediated formation of peroxycarboxylic acids used in catalytic epoxidation of alkenes. J. Chem. Soc. Chem. Commun. 1990, 1301-1303. [CrossRef]

70. Silva, W.S.D.; Lapis, A.A.M.; Suarez, P.A.Z.; Neto, B.A.D. Enzyme mediated epoxidation of methyl oleate supported by imidazolium based ionic liquid. J. Mol. Catal. B Enzym. 2011, 68, 98-103. [CrossRef]

71. De Torres, M.; Jiménez-Osés, G.; Mayoral, J.A.; Pires, E. Evaluation of several catalytic systems for epoxidation of methyl oleate using $\mathrm{H}_{2} \mathrm{O}_{2}$ as oxidant. Catal. Today 2012, 195, 76-82. [CrossRef]

72. Lu, H.; Sun, S.; Bi, Y.; Yang, G.; Ma, R.; Yang, H. Enzymatic epoxidation of soybean oil methyl esters in the presence of free fatty acids. Eur. J. Lipid Sci. Technol. 2010, 112, 1101-1105. [CrossRef]

73. Vlcek, T.; Petrovic, Z. Optimization of the chemoenzymatic epoxidation of soybean oil. J. Am. Oil Chem. Soc. 2006, 83, 247-252. [CrossRef]

74. Sun, S.; Yang, G.; Bi, Y.; Liang, H. Enzymatic epoxidation of corn oil by perstearic acid. J. Am. Oil Chem. Soc. 2011, 88, 1567-1571. [CrossRef]

75. Sun, S.; Ke, X.; Cui, L.; Yang, G.; Bi, Y.; Song, F.; Xu, X. Enzymatic epoxidation of Sapindus mukorossi seed oil by perstearic acid optimized using response surface methodology. Ind. Crop Prod. 2011, 33, 676-672. [CrossRef]

76. Schneider, R.C.S.; Lara, L.R.S.; Bitecourt, T.B.; Nascimento, M.G.; Nunes Marta, M.R. Chemoenzymatic epoxidation of sunflower oil methyl esters. J. Braz. Chem. Soc. 2009, 20, 1473-1477. [CrossRef]

77. Téllez, G.L.; Vigueras-Santiago, E.; Hermandez-Lopez, S. Characterization of linseed oil epoxidized at different percentages. Superf. Vacio 2009, 22, 5-10.

78. Kazariya, A.; Matsumura, S. Enzymatic synthesis and crosslinking of novel high molecular weight polyepoxyricinoleate. Polymers 2012, 4, 486-500. [CrossRef]

79. Aouf, Ch.; Durand, E.; Lecomte, J.; Figuerola-Espinoza, M.C.; Dubreucq, E.; Fulcrand, H.; Villeneuve, P. The use of lipases as biocatalysts for the epoxidation of fatty acids and phenolic compounds. Green Chem. 2014, 16, 1740-1754. [CrossRef]

80. Valivety, R.H.; Halling, P.J.; Peilov, A.D.; Macrae, A.R. Lipases from different sources vary widely in dependence of catalytic activity on water activity. Biochim. Biophys. Acta 1992, 1122, 143-146. [CrossRef]

81. Villeneuve, P. Lipases in lipophilization reactions. Biotechnol. Adv. 2007, 25, 515-536. [CrossRef] [PubMed]

82. Ku, M.A.; Hang, Y.D. Enzymatic synthesis of esters in organic medium with lipase from Byssochlamys fulva. Biotechnol. Lett. 1995, 17, 1081-1084. [CrossRef]

83. Yan, Y.; Bornscheuer, U.T.; Schmid, R. Lipase catalyzed synthesis of vitamin C fatty acid esters. Biotechnol. Lett. 1999, 21, 1051-1054. [CrossRef]

84. Boutur, O.; Dubreucq, E.; Galzy, P. Factors influencing ester synthesis catalyzed in aqueous media by the lipase from Candida deformans (Zach) Langeron and Guerra. J. Biotechnol. 1995, 42, 23-33. [CrossRef]

85. Severiano, A.; Hagström, A.; Hatti-Kaul, R.; Da Fonseca, M.M.R. Chemoenzymatic Epoxidation of Rapeseed Methyl Esters: Parameters Influencing the Reaction and Enzyme Stability. Available online: https:/ fenix.tecnico.ulisboa.pt/downloadFile/395137861152/Epoxidation\%20of\%20RME.pdf (access on 24 November 2015).

(C) 2015 by the authors; licensee MDPI, Basel, Switzerland. This article is an open access article distributed under the terms and conditions of the Creative Commons by Attribution (CC-BY) license (http:/ / creativecommons.org/licenses/by/4.0/). 